\title{
The effect of size of black cherry stumps on the composition of fungal communities colonising stumps
}

https://doi.org/10.1515/biol-2019-0054

Received February 12, 2019; accepted May 31, 2019

\begin{abstract}
We investigated fungal communities colonising black cherry stumps. We tested the hypothesis that black cherry stumps of greater diameter should be characterised by more diverse fungal communities than stumps of smaller diameter. The material for analyses came from Podanin Forest District. DNA was extracted using a Plant Genomic DNA purification kit. The results were subjected to bioinformatic analysis and statistical analysis. The OTU sequences were compared using the BLAST algorithm with reference sequences from the UNITE database. In total, 8192 raw sequences were obtained from samples of black cherry stumps applying the Illumina sequencing technique. The results of the statistical analysis indicate a trend towards increased diversity in bigger black cherry stumps. The dominant share of fungi associated with wood decomposition indicates the progressing process of decomposition in stumps. Identification of the role and functions of the individual components of fungal communities colonising stumps may provide insight into the overall ecology of these organisms and provide a basis for improved plant protection, with a view to limiting the occurrence of black cherries in the future in undesirable locations outside their natural range.
\end{abstract}

Keywords: Prunus serotina, Illumina System, saprotrophs, invasive species

\footnotetext{
*Corresponding author: Korzeniewicz Robert, Poznań University of Life Sciences, Department of Silviculture; ul. Wojska Polskiego 71A, 60-625 Poznań; Poland; korzon@up.poznan.pl;

Marlena Baranowska, Poznań University of Life Sciences, Department of Silviculture; ul. Wojska Polskiego 71A, 60-625 Poznań; Poland

Jolanta Behnke-Borowczyk, Poznań University of Life Sciences, Department of Forest Pathology, ul. Wojska Polskiego 71c, 60-625 Poznań; Poland
}

\section{Introduction}

Dynamic development of the black cherry (Prunus serotina) population has been observed in monocultures of Scots pine (Pinus sylvestris L.), plantations of black pine (P. nigra Arn.) and European larch (Larix decidua Mill.) [1], fresh mixed coniferous forest, fresh mixed forest and fresh forest stands [2,3]. When appearing on a mass scale in the shrub layer, black cherry hinders regeneration, growth and development of native tree species such as oak or pine, which lose in the competition e.g. for light [1]. For these reasons remedial action is being undertaken to limit the occurrence of black cherry. The methods used to control invasive species are frequently based on experience, rather than on the results of research [4]. Attempts to control black cherry based on methods which are not supported by the results of reliable evidence-based research may be inappropriate, and in the longer term a mistaken strategy, comparable in severity to the original intended introduction of that species [1].

One of the factors leading to the classification of a species as invasive is the lack of organisms that are antagonistic to it in the newly colonised environment [3]. Our current knowledge concerning antagonistic organisms, particularly fungi, in relation to the black cherry is far from satisfactory. In Poland very few studies have been published on the mycological pathogens of this host plant species or more broadly the genus Prunus $[5,6,4]$. The most numerous publications concern Chondrostereum purpureum (Pers.), which in Western Europe is used in the biological control of undesirable deciduous species, including the black cherry [7-9]. Observations in the Kampinos National Park provided information on the occurrence of macrofungi on decomposing black cherry wood $[10,4]$.

However, there are no reports on communities of microfungi colonising black cherry wood. In view of the above it was decided to investigate fungal communities 
colonising black cherry stumps. Herein, we tested the hypothesis that black cherry stumps of greater diameter should be characterised by more diverse and more numerous fungal communities than stumps of smaller diameter (i). It was also assumed that: the saprotrophs will dominate in the fungal communities of black cherry (ii), the Illumina system will identify the majority of fungi at the level of genus or species (iii), and the month of felling will have an influence on the fungal communities (iv).

\section{Materials and Methods}

The material for analyses consisted of 15 black cherry stumps of maximum $5 \mathrm{~cm}$ diameter outside bark (sample K1) and 15 stumps that were over $5 \mathrm{~cm}$ in diameter outside bark (sample K2), left after the trees had been felled in March, April and May in the Podanin Forest District $\left(19^{\circ} 28^{\circ} 00^{\prime \prime} \mathrm{E} 52^{\circ} 04^{\circ} 00^{\prime \prime} \mathrm{N}\right.$, the Margonin Forest Division, compartment 342a) (with 5 stumps in each month). The dominant forest site type was fresh mixed forest (LMśw), growing on a rusty brown soil (RDbr). From the selected stumps $2 \mathrm{~cm}$ discs were cut, which were then spot drilled using a SPARKY BUR 15E cordless impact drill with a $2 \mathrm{~mm}$ bit. The material collection procedure was performed according to [11]. Samples of pulverised wood were ground in a mortar frozen to $-70^{\circ} \mathrm{C}$. DNA was extracted using a Plant Genomic DNA purification kit (ThermoScientific). The protocol was modified to include extended lysis. The fungal community was identified to species based on the ITS $1 / 2$ rDNA region. Analysis was conducted using specific primers ITS FI2 $5^{\circ}$ GAA CCW GCG GAR TCA 3`and 5.8S 5`CGC TGC GTT CTT CAT 3` [12]. The reaction mixture was composed of $2.5 \mu \mathrm{LNA}, 0.2 \mu \mathrm{l}$ each primer, $10.6 \mu \mathrm{l}$ deionised water and $12.5 \mu \mathrm{l} 2 \mathrm{X}$ PCR MIX (A\&A Biotechnology). The amplification reaction was run in a thermocycler and included initial denaturation $\left(94^{\circ} \mathrm{C}\right.$ $5 \mathrm{~min}) ; 35$ cycles of denaturation $\left(94^{\circ} \mathrm{C} 30 \mathrm{~s}\right)$, annealing $\left(56^{\circ} \mathrm{C} 30 \mathrm{~s}\right)$ and elongation $\left(72^{\circ} \mathrm{C} 30 \mathrm{~s}\right)$; and final elongation $\left(72^{\circ} \mathrm{C} 7 \mathrm{~min}\right)$. Next, the product was verified on $1 \%$ agarose gel stained with Midori Green Advance DNA (Genetics). The product obtained was purified and sequenced using the SBS technology by Illumina (Genomed S.A. Warszawa).

The results were subjected to bioinformatic analysis (PIPITS, PEAR; FASTX, ITSx, UNITE) and statistical analysis. The OTU sequences were compared using the BLAST algorithm with reference sequences from the UNITE database. Identification was performed to the rank of the lowest possible taxon. A description of the individual stages of the bioinformatic and statistical analyses was given by Szewczyk et al. 2017 [13].

\section{Results}

In total, 8192 raw sequences were obtained from 18 samples of black cherry stumps applying the Illumina sequencing technique. This number includes sequences of culturable fungi $(6652=81.20 \%)$, non-culturable fungi $(540=6.59 \%)$ and organisms with no reference sequence in the database $(1001=12.21 \%)$. The stumps were colonised by 363 taxa. Cultured fungi of small stumps (K1): Ascomycota, Basidiomycota, Glomeromycota and Zygomycota were represented by 1134 (55.06\%), 286 (11.8\%), 6 (0.25\%) and $6(0.25 \%)$ taxa, respectively, comprising $85.15 \%$ of all taxa detected. In turn, cultured fungi from big stumps (K2), i.e. Ascomycota, Basidiomycota, Glomeromycota and Zygomycota, were represented by 3245 (56.25\%), 1265 (21.93\%), $1(0.02 \%)$ and $28(0.49 \%)$ taxa, respectively. Non-culturable organisms were represented by 310 taxa in samples K1 and 335 in samples K2.

\begin{tabular}{lll}
\hline & Spring K1 & Spring K2 \\
\hline D-Mg index & 13.9807 & 34.1791 \\
Shannon`s diversity index H & 2.4793 & 3.5573 \\
Shannon`s evenness index E & 0.5275 & 0.6248 \\
Simpson's diversity index & 0.14 & 0.0731 \\
Berger-Parker Dominance index & 0.1258 & 0.16 \\
\hline
\end{tabular}

Margalef's index (DMg), Shannon's diversity index $(\mathrm{H})$ and Simpson's diversity index (D) indicate a trend towards increased diversity in bigger black cherry stumps (K2) (Table 1). Similarly, the dominance of single taxa in communities in larger stumps (K2) resulted in low values for Shannon's evenness index (E) and high values for Berger-Parker's dominance index (d).

The most common fungi in small stumps (K1) included Pleurophoma ossicola (25.46\%), Mycena megaspora (5.49\%), Trichosporon otae (3.26\%), Penicillium citreonigrum (2.93\%), Yarrowia lipolytica (2.06\%), $P$. lapidosum (2.35\%) Blastobotrys sp. (2.02\%), and Candida fructus (1.98\%). However, in larger stumps (K2) the most common fungi were Proliferodiscus sp. (14.75\%), Laetiporus sulphureus (3.73\%), Tumularia sp. (2.24\%), Cuniculitrema polymorpha (1.84\%), Curvibasidium cygneicollum (1.61\%), C. mycetangii (1.42\%), Biatora sphaeroidizax (1.37\%), Rhizoscyphus sp. (1.32\%), Fellozyma inositophila (1.23\%), Hamamotoa lignophila (1.04\%) (Tab. 2).

The fungi found on both small and large stumps were Beauveria pseudobassiana, Chalara sp., Ciborinia candolleana, Dictyochaeta sp., Infundichalara minuta, Jattaea ribicola, Lachnellula calyciformis, Penicillium 
bialowiezense, $P$. citreonigrum, $P$. lapidosum, P. raphiae, Phialocephala compacta, Pleurophoma ossicola, Proliferodiscus sp., Sordariomycetes sp., Tumularia sp., Agaricomycetes sp., Microstroma album, Mycena megaspora, Vishniacozyma victoriae, Rozellomycota sp. and Umbelopsis isabellina.

\section{Discussion}

Greater diversity of fungal species in the community was observed for black cherry stumps exceeding $5 \mathrm{~cm}$ in diameter. In both cases the fungal community was dominated by fungi from the Phylum Ascomycota, with their share slightly exceeding 55\% in the analysed communities, as confirmed by earlier reports concerning deciduous trees $[14,15]$. These results indicate that the dominance of Ascomycota in the fungal community associated with dead wood is also related to the degree of its decomposition, i.e. the earlier the decomposition stage of wood, the greater the share of Ascomycota in the community [16-20]. The analysed stumps were classified into wood decomposition class 1 and samples were collected 1 year after the black cherries were removed from the stand, thus the recorded results confirm earlier reports. Fungi belonging to the Phylum Ascomycota cause slow wood decomposition, which is limited only to surface decay in periods of increased humidity. However, alternating drought and wet periods promote deeper penetration of the mycelium and lead to extended wood decomposition [21]. In turn, in the analysed community the share of taxa belonging to the Phylum Basidiomycota was almost 2-fold greater in the community of black cherry stumps with diameters exceeding $5 \mathrm{~cm}$ than in black cherry stumps with diameters not exceeding $5 \mathrm{~cm}$. A lesser share was recorded for taxa belonging to the Phylum Basidiomycota. Similar results were also reported by van der Wall et al. 2015 [22] and Kwaśna et al. 2016 [15].

Pleurophoma ossicola was the taxon found most frequently on black cherry stumps of lesser diameter (over 25\%), although it was also recorded to some extent on larger stumps (0.23\%). It was found in a stand with Scots pine in Germany [23]. The literature lacks data on the function of this fungus in the community. The rotting bonnet fungus (Mycena megaspora) was one of the most abundant species recorded in the fungal community of black cherry stumps (K1, 5.49\%), as well as a species common for both analysed variants (K1 and K2). Fungi belonging to that genus are most frequently classified as saprotrophs, except for M. citricolor (Ber. \& Curt.). Fungi from the genus Mycena are commonly found on dead wood of coniferous trees and angiosperms, on decomposing stems and branches, on the bark of living trees, in soil, and less frequently on decomposing ferns, grasses or other herbaceous plants and mosses [24].

In the fungal community of black cherry stumps of over $5 \mathrm{~cm}$ in diameter (K2) the most abundant taxon was Proliferodiscus, which was a common taxon for both analysed black cherry communities. Fungi from that genus play an important role in the decomposition of various organic substances, including dead wood, branches and leaf litter. An example is provided by P. pulveraceus, a new species in Poland discovered in 2008, which is found on dead hornbeam wood [25].

Beauveria pseudobassiana was a common species in both analysed communities; nevertheless, its share was below $1 \%$. This genus includes $B$. bassiana and $B$. brongniartii, used in biological control of harmful insects [26]. The genus Chalara was also found to be a common taxon for both communities, comprising pathogens such as Ch. fraxinea causing ash die-back $[27,28]$. Other taxa recorded in both communities were Ciborinia candolleana, Dictyochaeta, and Infundichalara minuta, which is classified as a saprotrophic species [29-31]. Lachnellula calyciformis was another species common in both communities; as a saprotroph it colonises knots, snags, dead branches and twigs, and, less commonly, living trees [32]. Other species common for both communities of black cherry stumps include Penicillium bialowiezense, which so far has been isolated from forest soil (in Poland), as well as $P$. raphiae found in soil [33]. In both cases Microstroma album was identified, which is classified as an obligate parasite of Quercus [34].

The available literature still lacks reports thoroughly detailing communities of fungi colonising black cherry stumps. Information on fungi on roots of that species and studies of Macromycetes colonising black cherry wood have been published by Kwaśna et al. 2008 [35]. Similarly, as reported by Kwaśna et al. 2008 [35], in the current study of the community of fungi colonising black cherry stumps species from the genus Mycena were recorded, e.g. M. cinerella, M. galericulata, $M$. megaspora and $M$. sanguinolenta. In the fungal community colonising stumps exceeding $5 \mathrm{~cm}$, similarly to the study by Kwaśna et al. 2008 [35], we found a small group of fungi from the genus Fusarium and a single species $F$. cyanostomum, as well as Humicola spp. Sporothrix dimorphospora. In stumps of less than $5 \mathrm{~cm}$ in diameter a fungal species from the genus Trichoderma was identified: T. asperellum. In wood of stumps of all black cherry trees, fungi from the genus Penicillium were identified, although this community differed from that reported in black cherry roots. In black 
cherry stumps the following Penicillium fungi were found: $P$. angulare, $P$. bialowiezense, $P$. citreonigrum, $P$. kongii, $P$. lanosum, $P$. lapidosum, $P$. miczynskii, $P$. raphiae and $P$. viticola. Identification of fungal communities in black cherry roots and stumps was not consistent due to the differences in the analysed material and the methods applied to identify the respective communities. In the Kampinos National Park in the wood of black cherries subjected to mechanical control, analysis showed the presence of Nectria cinnabarina (Tode) Fr. anamorph [4], while in the case analyses of stumps a sparse share $(>1 \%)$ of Nectriaceae was found. Other differences were found in the species Mycena galericulata [4], which was also identified on stumps with diameters of less than $5 \mathrm{~cm}$, and M. haematopus (Pers.) P. Kumm; Peniophora cinerea (Pers.) Cooke; Phaeotremella pseudofoliacea Rea and Stereum rugosum [4], which we identified in the wood of larger stumps. Stereum rugosum was only recorded in approximately $2 \%$ of trees, but accounted for approximately $7 \%$ of trees which were colonised by fungi. This species is mainly saprotrophic in character. Locally it causes bark necroses or cankers on stems of deciduous trees [36]. In the Kampinos National Park Laetiporus sulphureus has been reported on logs, branches and trees of the black cherry [4], while in this study it had a 3.76\% share in wood of stumps with diameters larger than 5 $\mathrm{cm}$. Stereum hirsutum was identified in this study in the wood of larger black cherry stumps, as well as Tremella mesenterica Retz [4], whereas in our study a share of the genus Tremella was identified in this community.

\section{Conclusion}

The results of the above-mentioned study are consistent with our hypothesis that larger black cherry stumps should be characterised by a more diverse fungal species composition both qualitatively and quantitatively. Taking into account this study's results, it seems justified to undertake further studies on the species Pleurophoma ossicola, whose share in black cherry stumps with diameters of maximum $5 \mathrm{~cm}$ exceeded $25 \%$, while its ecology and function in the forest environment have not been thoroughly identified to date.

Saprotrophs and pathogens, both termed facultative parasites, that are primarily found in the analysed black cherry stumps include Proliferodiscus sp., Laetiporus sulphureus, Mycena megaspora, Trichosporon otae, Yarrowia lipolytica, Tumularia and Curvibasidium cygneicollum. The dominant share of fungi associated with wood decomposition indicates the progressing process of decomposition in stumps; however, the rate of black cherry wood decomposition by the above-mentioned taxa has not been determined. In the fungal community of black cherry stumps we did not find any economically important pathogens associated with tree root systems, for example genera such as Armillaria and Heterobasidion. Using the criterion of a $1 \%$ share in the community, we recorded the presence of a mycorrhizal fungus Rhizoscyphus sp. associated with the family Ericaceae. Moreover, we also identified fungi which to date have been considered to have no economic importance in the forest economy.

The applied sequencing method based on the Illumina System made it possible to identify most fungi (nearly 90\%) to the genus or species levels. Classification of fungi was more effective than in studies based on 454 sequencing, in which $40 \%$ sequences were unidentified even at the genus level $[19,20]$. This confirms the efficacy of the applied method for determining and defining the composition of fungal communities.

The analysis of the quantitative and qualitative composition undertaken in our study on fungal communities colonising black cherry stumps is in line with basic research on this species. Identification of the role and functions of the individual components of fungal communities colonising stumps may provide some insight into the overall ecology of these organisms and provide a basis for improved plant protection and control, with a view to limiting the occurrence of black cherries in the future in undesirable locations outside their natural range. Our study is an introduction into an analysis of variability in the structure of the above-mentioned community.

Acknowledments: This study was co-financed by the State Forests National Forest Holding, General Directorate of the State Forests in Warsaw, programme as "Development of methods for combating Black cherry in pine stands” (Project number OR.271.3.13.2017).

Conflict of interest: Authors state no conflict of interest.

\section{References}

[1] Starfinger U, Kowarik I, Rode M, Schepker H. From desirable ornamental plant to pest to accepted additional to the flora? - the perception of alien tree species through the centuries. Biological Invasions 2003; 5: 323-335.

[2] Rutkowski P, Maciejewska-Rutkowska I, Łabędzka M. Wtaściwy dobór składu gatunkowego drzewostanów jako jeden ze sposobów walki z czeremchą amerykańską (Prunus serotina Ehrh.). Acta Scientiarum Poloniae Silvarum Colendarum Ratio et Industria Lignaria. 2002; 1, 2: 59-73. 
[3] Halarewicz A. Właściwości ekologiczne i skutki rozprzestrzeniania się czeremchy amerykańskiej Padus serotina (Ehrh.) Borkh. w wybranych fitocenozach leśnych. Wydawnictwo Uniwersytetu Przyrodniczego we Wrocławiu, Wroctaw, 2012; 143 p.

[4] Marciszewska K, Szczepkowski A, Otręba A, Oktaba L, Kondras M, Zaniewski P, Ciurzycki W, Wojtan R, The dynamics of sprouts generation and colonization by macrofungi of black cherry Prunus serotina Ehrh. eliminated mechanically in the Kampinos National Park. Folia Forestalia Polonica, Series A Forestry, 2018; 60(1), 34-51.

[5] Wojewoda W. Checklist of Polish larger Basidiomycetes. In: Mirek Z. Biodiversity of Poland, vol. 7, Szafer Institute of Botany, Polish Academy of Sciences, Kraków, Poland. 2003.

[6] Karasiński D, Kujawa A, Gierczyk B, Ślusarczyk T, Szczepkowski A, Macrofungi of Kampinos National Park. Kampinoski Park Narodowy, Izabelin, Poland. 2015.

[7] Van den Meersschaut D, Lust N, Comparison of mechanical, biological and chemical methods for controlling black cherry (Prunus serotina) in Flanders (Belgium). Silva Gandavensis, 1997; 62, 90-109.

[8] De Jong, MD. The BioChon story: deployment of Chondrostereum purpureum to suppress stump sprouting in hardwoods. Mycologist, 2000; 14 (2), 58-62.

[9] Roy V, Dubeau D, Auger I, Biological control of intolerant hardwood competition: Silvicultural efficacy of Chondrostereum purpureum and worker productivity in conifer plantations. Forest Ecology and Management, 2010; 259, 1571-1579.

[10] Namura-Ochalska A, Borowa B. The struggle against black cherry Padus serotina (Ehrh.) Borkh. in the forest division Rózin of the Kampinos National Park. Assessment of the effectiveness of selected methods. In: Krzysztofiak L, Krzysztofiak A, Elimination of invasive alien plant species good and bad practices, Stowarzyszenie "Cztowiek i Przyroda", Krzywe, Poland, 2015; 57-74.

[11] Hoppe B, Kahl T, Karasch P, Wubet T, Bauhus J, Buscot F, Krüger D. Network analysis reveals ecological links between $\mathrm{N}$-fixing bacteria and wood-decaying fungi PLoS One, 2014; 9: e88141, doi: 10.1371/journal.pone.0088141

[12] Schmidt PA, Bálint M, Greshake B, Bandow C, Römbke J, Schmitt I. Illumina metabarcoding of a soil fungal community. Soil Biology \& Biochemistry. 2013; 65: 128-132. http://dx.doi. org/10.1016/j.soilbio.2013.05.014.

[13] Szewczyk W, Kwaśna H, Behnke-Borowczyk J. Fungi inhabiting knotwood of Pinus sylvestris infected by Porodaedalea pini. Journal of Phytopathology. 2017; 165(7-8): 500-507. doi: org/10.1111/jph.12586

[14] Gutowski JM, Bobiec A, Pawlaczyk P, Zub KB. Drugie życie drzew (The second life of a tree). WWF, Warszawa-Hajnówka. 2004.

[15] Kwaśna $H$, Mazur A, Łabędzki A, Kuźmiński R, Łakomy P. Communities of fungi in decomposed wood of oak and pine. Leśne Prace Badawcze 2016; 77(3): 261-275. doi: 10.1515-frp2016-0028.

[16] Rajala T, Peltoniemi M, Hantula J, Mäkipää R, Pennanen T. RNA reveals a succession of active fungi during the decay of Norway spruce logs. Fungal Ecology. 2011; 4: 437-448. doi: org/10.1016/j.funeco.2011.05.005.
[17] Rajala T, Peltoniemi M, Pennanen T, Mäkipää R. Fungal community dynamics in relation to substrate quality of decaying Norway spruce (Picea abies [L.] Karst.) logs in boreal forests. FEMS Microbiology Ecology 2012; 81: 494-505. doi: 10.1111/j.1574-6941.2012.01376.x.

[18] Rajala T, Tuomivirta T, Pennanen T, Mäkipää R. Habitat models of wood inhabiting fungi along a decay gradient of Norway spruce logs. Fungal Ecology. 2015; 18: 48-55. doi: org/10.1016/j.funeco.2015.08.007.

[19] Kubartová A, Ottosson E, Dahlberg A, Stenlid J. Patterns of fungal communities among and within decaying logs, revealed by 454 sequencing. Molecular Ecology. 2012; 21: 4514-4532. doi: 10.1111/j.1365-294X.2012.05723.x.

[20] Ovaskainen O, Schigel D, Ali-Kovero H, Auvinen P, Paulin L, Norden B, Norden J. Combining high-throughput sequencing with fruit body surveys reveals contrasting life-history strategies in fungi. International Society for Microbial Ecology Journal. 2013; 7(9): 1696-1709. doi: 10.1038/ismej.2013.61.

[21] Eaton RA, Hale MDC. Wood: decay, pests and protection. Chapman \& Hall, 1993; pp. 1-519.

[22] Van der Wal A, Ottosson E, de Boer W. Neglected role of fungal community composition in explaining variation in wood decay rates. Ecology. 2015; 96: 124-133.

[23] Crous, PW, Wingfield MJ, Guarro et al,. Fungal Planet description sheets: 320-370. Persoonia- Molecular Phylogeny and Evolution of Fungi. 2015; 34: 167-266.

[24] Perry BA. A taxonomic investigation of mycena in California. A thesis submitted to the Faculty of San Francisco State University in partial fulfillment of the requirements for the degree. Master of Arts. In Biology: Ecology and Systematic Biology. San Francisco, California, 2002; 162 pp.

[25] Bodziarczyk J, Chachuła P. Charakterystyka przyrodnicza rezerwatu „Cisy w Serednicy” w Górach Stonnych (Bieszczady Zachodnie). Roczniki Bieszczadzkie. 2008; 16:179-190.

[26] Zimmermann G, Review on safety of the entomopathogenic fungi Beauveria bassiana and Beauveria brongniartii. Biocont. Sci. Technol., 2007; 17: 553- 596.

[27] Doroszewska T, Przybyś M. Charakterystyka odporności gatunków Nicotiana na czarną zgniliznę korzeni Thielaviopsis basicola (Berk. and Broome) Ferr. Zeszyty Problemowe Postępów Nauk Rolniczych. 2007; 517: 253-266.

[28] Orzechowski M, Kacprzak J, Kędziora W. Zamieranie jesionu wyniostego (Fraxinus excelsior L.) w rezerwacie Jesionowe Góry, Leśne Prace Badawcze. 2016; 77 (2): 124-133.

[29] Phillips DH, Burdekin DA. Diseases of Forest and Ornamental Trees. Springer, 1992; $581 \mathrm{pp}$.

[30] Cruz ACR, Leão-Ferreira SM, Barbosa FR, Gusmão LFP. Conidial fungi from semi-arid Caatinga biome of Brazil. New and interesting Dictyochaeta species. Mycotaxon 106, 2008; 15-27.

[31] Koukol O. A new species of Infundichalara from pine litter. Mycotaxon - Ithaca Ny- 2012; 120(1) :343-352.

[32] Minter DW. Lachnellula calyciformis. IMI Descriptions of Lachnellula Calyciformis Fungi and Bacteria. CABI Bioscience, Bakeham Lane, Egham, Surrey, UK, 2005; 1642: 1-4.

[33] Paul NC, Mun HY, Lee HW, Yu SH, Lee HB, A new record of Penicillium raphiae isolated from agricultural soil of Ulleung Island, Korea. Mycobiology; 2014., 42(3): 282-285.

[34] Fodor E, Hâruţa O. Microstroma album (Desm.) Sacc. and Microstroma juglandis (Berenger) Sacc. in North Western 
Romania. Analele Universităţii din Oradea, Fascicula Protecţia Mediului. 2014. XXIII: 427-438.

[35] Kwaśna H, Bateman GL, Ward E. Determining species diversity of microfungal communities in forest tree roots by pure-culture isolation and DNA sequencing. Applied Soil Ecology Volume. 2008; 40(1): 44-56.

[36] Butin H. Tree diseases and disorders. Oxford University Press, Oxford, England, 1995; 252 pp. 


\begin{tabular}{lllll}
\hline No. Taxon & K1 & K2 & \\
\cline { 3 - 6 } & $\%$ & $\%$ & $\%$ & $\%$
\end{tabular}

Fungi

\section{Ascomycota}

1. Absconditella sp.

$0.000 \quad 0.017$

2. Acephala applanata Grünig \& T.N. Sieber

0.124

0.000

3. Alatospora sp.

0.000

0.017

4. Arachnopeziza sp.

0.000

0.312

5. Articulospora sp.

0.000

0.017

6. Ascomycota

12.629

15.999

7. Barssia maroccana G. Moreno, Manjón, Carlavilla \& P. Alvarado

0.124

0.000

8. Beauveria pseudobassiana S.A. Rehner \& Humber

0.083

0.104

9. Biatora sphaeroidiza Printzen \& Holien

0.000

1.369

10. Bionectriaceae

0.000

0.017

11. Blastobotrys sp.

2.022

0.000

12. Cadophora luteo-olivacea (J.F.H. Beyma) T.C. Harr. \& McNew

0.000

0.087

13. Caliciopsis beckhausii (Körb.) Garrido-Ben. \& Pérez-Ort.

0.000

0.052

14. Candida fructus (Nakase) S.A. Mey. \& Yarrow +C. mycetangii Kurtzman+ Candida sp.

1.981

1.487

15. Capronia pilosella (P. Karst.) E. Müll., Petrini, P.J. Fisher, Samuels \& Rossman + C. pulcherrima

0.000

0.087

16. Cephalosporium sp.

0.000

0.017

17. Cephalothecaceae

0.083

0.503

18. Chaetomium sp.

0.000

0.017

19. Chaetothyriales

0.000

0.589

20. Chalara sp.

0.041

0.017

21. Chloridium sp.

0.124

0.000

22. Ciborinia candolleana (Lév.) Whetzel

0.041

0.017

23. Ciliophora sp.

0.124

0.000

24. Cladophialophora arxii Tintelnot + Cladophialophora sp.

0.000

0.364

25. Claussenomyces

0.000

0.017

26. Collophora sp.

0.000

0.104

27. Colpoma quercinum (Pers.) Wallr.

0.000

0.017

28. Coniochaeta sp.

0.000

0.121

29. Crocicreas epicalamia (Fuckel) Raitv. \& Kutorga + Crocicreas sp.

0.206

0.017

30. Cyphellophora reptans (de Hoog) Réblová \& Unter.

0.000

0.191

31. Dermateaceae

0.206

0.052

32. Desertella sp.

0.000

0.156

33. Diaporthe helicis Niessl

0.000

0.035

34. Dictyochaeta sp.

0.165

0.017

35. Discosia pseudoartocreas Crous \& Damm

0.000

0.069

36.

Discostroma sp.

0.000

0.069 


\begin{tabular}{|c|c|c|c|}
\hline \multirow[t]{2}{*}{ No. } & \multirow[t]{2}{*}{ Taxon } & \multirow{2}{*}{$\frac{\mathrm{K} 1}{\%}$} & K2 \\
\hline & & & $\%$ \\
\hline 37. & $\begin{array}{l}\text { Exophiala bergeri Haase \& de Hoog }+ \text { E. castellanii Iwatsu, Nishim. \& Miyaji }+ \text { E. psychrophila } \\
\text { O.A. Pedersen \& Langvad }+ \text { E. sideris Seyedm. \& de Hoog }+ \text { Exophiala sp. }\end{array}$ & 0.000 & 1.005 \\
\hline 38. & Fusarium cyanostomum (Sacc. \& Flageolet) O’Donnell \& Geiser +Fusarium sp. & 0.000 & 1.004 \\
\hline 39. & Fusicladium cordae Koukol & 0.000 & 0.017 \\
\hline 40. & Geomyces auratus Traaen & 0.000 & 0.035 \\
\hline 41. & Helotiaceae & 0.000 & 0.624 \\
\hline 42. & Helotiales & 1.197 & 0.312 \\
\hline 43. & Herpotrichiellaceae sp. & 0.041 & 2.704 \\
\hline 44. & Humicola sp. & 0.000 & 0.416 \\
\hline 45. & Hyalorbilia inflatula (P. Karst.) Baral \& G. Marson & 0.000 & 0.017 \\
\hline 46. & Hyaloscyphaceae & 0.000 & 0.035 \\
\hline 47. & Hydnotrya tulasnei (Berk.) Berk. \& Broome & 0.041 & 0.000 \\
\hline 48. & Hyphodiscus hymeniophilus (P. Karst.) Baral & 0.000 & 0.052 \\
\hline 49. & Hypocreales & 0.165 & 0.537 \\
\hline 50. & Hypomyces lactifluorum (Schwein.) Tul. \& C. Tul. & 0.000 & 0.017 \\
\hline 51. & Infundichalara minuta Koukol & 0.206 & 0.052 \\
\hline 52. & Jattaea aphanospora Réblová \& J. Fourn. & 0.000 & 0.104 \\
\hline 53. & Jattaea ribicola Réblová \& Jaklitsch & 0.041 & 0.035 \\
\hline 54. & Junewangia queenslandica (Matsush.) J.W. Xia \& X.G. Zhang & 0.000 & 0.069 \\
\hline 55. & Lachnellula calyciformis (Batsch) Dharne & 0.413 & 0.156 \\
\hline 56. & Lecania sp. & 0.000 & 0.017 \\
\hline 57. & Lecanicillium muscarium (Petch) Zare \& W. Gams & 0.000 & 0.035 \\
\hline 58. & Lecanorales & 0.000 & 0.017 \\
\hline 59. & Lecanoromycetes & 0.000 & 0.329 \\
\hline 60. & Lecophagus sp. & 0.000 & 0.347 \\
\hline 61. & Leotiomycetes & 0.083 & 0.988 \\
\hline 62. & Lepraria elobata Tønsberg & 0.000 & 0.069 \\
\hline 63. & Leptodontidium trabinellum (P. Karst.) Baral, Platas \& R. Galán & 0.000 & 0.329 \\
\hline 64. & Lophium arboricola (Buczacki) Madrid \& Gené & 0.000 & 0.052 \\
\hline 65. & Lophodermium pinastri (Schrad.) Chevall. & 0.454 & 0.000 \\
\hline 66. & Menispora manitobaensis B. Sutton & 0.000 & 0.156 \\
\hline 67. & Metapochonia bulbillosa (W. Gams \& Malla) Kepler, S.A. Rehner \& Humber & 0.000 & 0.087 \\
\hline 68. & Micarea assimilata (Nyl.) Coppins & 0.000 & 0.017 \\
\hline 69. & Mollisia cinerea (Batsch) P. Karst. & 0.000 & 0.017 \\
\hline 70. & Mycoleptodiscus sp. & 0.000 & 0.035 \\
\hline 71. & Nectriaceae & 0.000 & 0.052 \\
\hline 72. & Neofabraea sp. & 0.000 & 0.087 \\
\hline 73. & Oidiodendron majus G.L. Barron & 0.000 & 0.017 \\
\hline 74. & Onygenaceae & 0.000 & 0.052 \\
\hline
\end{tabular}




\begin{tabular}{|c|c|c|c|}
\hline \multirow[t]{2}{*}{ No. } & \multirow[t]{2}{*}{ Taxon } & \multirow{2}{*}{ K1 } & K2 \\
\hline & & & $\%$ \\
\hline 75. & Ophiostoma tsotsi Grobbel., Z.W. De Beer \& M.J. Wingf.si & 0.000 & 0.069 \\
\hline 76. & Ophiostomataceae & 0.000 & 0.087 \\
\hline 77. & Orbilia aprilis Velen. + O.aristata (Velen.) Velen. & 0.000 & 0.156 \\
\hline 78. & Orbiliomycetes sp. & 0.000 & 0.052 \\
\hline 79. & Otidea subterranea Healy \& M.E. Sm. & 0.000 & 0.069 \\
\hline 80. & Pannaria athroophylla (Stirt.) Elvebakk \& D.J. Galloway & 0.000 & 0.087 \\
\hline 81. & Parmelia subdivaricata Asahina & 0.000 & 0.017 \\
\hline 82. & $\begin{array}{l}\text { Penicillium angulare S.W. Peterson, E.M. Bayer \& Wicklow + P. bialowiezense K.W. Zaleski + P. } \\
\text { citreonigrum Dierckx + P. kongii L. Wang + P. lanosum Westling + P. lapidosum Raper \& Fennell } \\
+ \text { P. miczynskii K.W. Zaleski P. raphiae Houbraken, Frisvad \& Samson + P. viticola Nonaka \& } \\
\text { Masuma }\end{array}$ & 5.365 & 1.144 \\
\hline 83. & Pezicula sporulosa Verkley & 0.000 & 0.191 \\
\hline 84. & Phacidium grevilleae Crous \& M.J. Wingf. & 0.000 & 0.173 \\
\hline 85. & Phaeomollisia piceae T.N. Sieber \& Grünig & 0.000 & 0.035 \\
\hline 86. & Phaeomoniella sp. & 0.000 & 0.017 \\
\hline 87. & $\begin{array}{l}\text { P. compacta Kowalski \& Kehr + P. glacialis Grünig \& T.N. Sieber + P. scopiformis Kowalski \& } \\
\text { Kehr + Phialocephala sp. }\end{array}$ & 0.330 & 0.572 \\
\hline 88. & Picoa juniperi Vittad. & 0.000 & 0.676 \\
\hline 89. & Pleurophoma ossicola Crous, Krawczynski \& H.-G. Wagner & 25.464 & 0.225 \\
\hline 90. & Proliferodiscus sp. & 0.413 & 14.751 \\
\hline 91. & Pseudeurotiaceae & 0.000 & 0.035 \\
\hline 92. & Pseudogymnoascus verrucosus A.V. Rice \& Currah & 0.000 & 0.451 \\
\hline 93. & Rhizoscyphus sp. & 0.000 & 1.317 \\
\hline 94. & Saccharomycetales & 0.000 & 0.260 \\
\hline 95. & Sarea resinae (Fr.) Kuntze & 0.000 & 0.069 \\
\hline 96. & Sarocladium strictum (W. Gams) Summerb. & 0.000 & 0.711 \\
\hline 97. & Sordariales & 0.000 & 0.017 \\
\hline 98. & Sordariomycetes sp. & 0.083 & 0.416 \\
\hline 99. & Sporothrix dimorphospora (Roxon \& S.C. Jong) Madrid, Gené, Cano \& Guarro & 0.000 & 0.208 \\
\hline 100. & Stachybotrys sp. & 0.000 & 0.260 \\
\hline 101. & $\begin{array}{l}\text { Talaromyces amestolkiae N. Yilmaz, Houbraken, Frisvad \& Samson + T. verruculosus (Peyronel) } \\
\text { Samson, N. Yilmaz, Frisvad \& Seifert }+T \text {. wortmannii C.R. Benj. }\end{array}$ & 0.165 & 0.070 \\
\hline 102. & Taphrina confusa (G.F. Atk.) Giesenh. & 0.000 & 0.035 \\
\hline 103. & Tolypocladium sp. & 0.000 & 0.087 \\
\hline 104. & Trichoderma asperellum Samuels, Lieckf. \& Nirenberg & 0.371 & 0.000 \\
\hline 105. & Tridentaria implicans Drechsler & 0.000 & 0.035 \\
\hline 106. & Trimmatostroma cordae N.D. Sharma \& S.R. Singh & 0.000 & 0.017 \\
\hline 107. & Truncatella restionacearum S.J. Lee \& Crous & 0.000 & 0.087 \\
\hline 108. & Tumularia sp. & 0.083 & 2.236 \\
\hline 109. & Valsaceae & 0.041 & 0.347 \\
\hline 110. & Venturia hystrioides (Dugan, R.G. Roberts \& Hanlin) Crous \& U. Braun +Venturia sp. & 0.000 & 0.168 \\
\hline
\end{tabular}




\begin{tabular}{|c|c|c|c|}
\hline \multirow[t]{2}{*}{ No. } & \multirow[t]{2}{*}{ Taxon } & \multirow{2}{*}{$\frac{\mathrm{K} 1}{\%}$} & K2 \\
\hline & & & $\%$ \\
\hline 111. & Venturiaceae & 0.000 & 0.035 \\
\hline 112. & Venturiales & 0.000 & 0.069 \\
\hline 113. & Xenopolyscytalum pinea Crous & 0.000 & 0.017 \\
\hline 114. & Xylariaceae & 0.083 & 0.000 \\
\hline 115. & Yamadazyma mexicana (M. Miranda, Holzschu, Phaff \& Starmer) Billon-Grand & 0.000 & 0.052 \\
\hline \multirow[t]{2}{*}{116.} & Yarrowia lipolytica (Wick., Kurtzman \& Herman) Van der Walt \& Arx & 2.064 & 0.000 \\
\hline & Frequency of Ascomycota & 55.056 & 56.249 \\
\hline \multicolumn{4}{|c|}{ Basidiomycota } \\
\hline 1. & Agaricaceae & 0.083 & 0.035 \\
\hline 2. & Agaricales & 0.165 & 0.052 \\
\hline 3. & Agaricomycetes sp. & 0.041 & 0.017 \\
\hline 4. & Agaricostilbales & 0.000 & 0.017 \\
\hline 5. & Amanita parcivolvata (Peck) E.-J. Gilbert & 0.000 & 0.017 \\
\hline 6. & Auriculariales & 0.041 & 0.000 \\
\hline 7. & Basidiomycota & 0.537 & 1.161 \\
\hline 8. & Bullera sp. & 0.000 & 0.017 \\
\hline 9. & Bulleromyces albus Boekhout \& Á. Fonseca & 0.000 & 0.017 \\
\hline 10. & Cantharellales & 0.083 & 0.000 \\
\hline 11. & Chionosphaera cuniculicola R. Kirschner, Begerow \& Oberw. & 0.000 & 0.017 \\
\hline 12. & Chrysozymaceae & 0.000 & 0.017 \\
\hline 13. & Clitopilus hobsonii (Berk.) P.D. Orton & 0.000 & 0.052 \\
\hline 14. & $\begin{array}{l}\text { Colacogloea philyla (Van der Walt, Klift \& D.B. Scott) Q.M. Wang, F.Y. Bai, M. Groenew. \& } \\
\text { Boekhout }\end{array}$ & 0.000 & 0.087 \\
\hline 15. & Colacogloea & 0.000 & 0.052 \\
\hline 16. & Corticium confine Bourdot \& Galzin & 0.000 & 0.017 \\
\hline 17. & $\begin{array}{l}\text { Cryptococcus pseudolongus M. Takash., Sugita, Shinoda \& Nakase + C. psychrotolerans V. de } \\
\text { García, Zalar, Brizzio, Gunde-Cim. \& Van Broock + Cryptococcus sp. }\end{array}$ & 0.041 & 0.671 \\
\hline 18. & Cuniculitrema polymorpha R. Kirschner \& J.P. Samp. & 0.000 & 1.837 \\
\hline 19. & Curvibasidium cygneicollum J.P. Samp. & 0.000 & 1.612 \\
\hline 20. & Cystobasidiomycetes & 0.000 & 0.069 \\
\hline 21. & $\begin{array}{l}\text { Cystobasidium pinicola (F.Y. Bai, L.D. Guo \& J.H. Zhao) Yurkov, Kachalkin, H.M. Daniel, M. } \\
\text { Groenew., Libkind, V. de Garcia, Zalar, Gouliamova, Boekhout \& Begerow }\end{array}$ & 0.000 & 0.537 \\
\hline 22. & Cystofilobasidiales & 0.000 & 0.173 \\
\hline 23. & $\begin{array}{l}\text { Cystofilobasidium infirmominiatum (Fell, I.L. Hunter \& Tallman) Hamam., Sugiy. \& Komag. +C. } \\
\text { macerans J.P. Samp. }\end{array}$ & 0.000 & 0.069 \\
\hline 24. & Dacrymyces chrysospermus Berk. \& M.A. Curtis & 0.000 & 0.485 \\
\hline 25. & Dioszegia fristingensis Á. Fonseca, J. Inácio \& J.P. Samp. & 0.000 & 0.017 \\
\hline 26. & Erythrobasidiales & 0.000 & 0.069 \\
\hline 27. & Erythrobasidium sp. & 0.000 & 0.052 \\
\hline 28. & Exobasidium arescens Nannf. + E. maculosum M.T. Brewer + Exobasidium sp. & 0.000 & 0.624 \\
\hline
\end{tabular}




\begin{tabular}{|c|c|c|c|}
\hline \multirow[t]{2}{*}{ No. } & \multirow[t]{2}{*}{ Taxon } & \multirow{2}{*}{$\frac{\mathrm{K} 1}{\%}$} & K2 \\
\hline & & & $\%$ \\
\hline 29. & $\begin{array}{l}\text { Fellomyces horovitziae Spaaij, G. Weber \& Oberw. + F. mexicanus Lopandić, O. Molnár \& } \\
\text { Prillinger + Fellomyces sp. }\end{array}$ & 0.000 & 0.069 \\
\hline 30. & Fellozyma inositophila (Nakase \& M. Suzuki) Q.M. Wang, F.Y. Bai, M. Groenew. \& Boekhout & 0.000 & 1.231 \\
\hline 31. & Fibulobasidium murrhardtense J.P. Samp., Gadanho, M. Weiss \& R. Bauer & 0.000 & 0.035 \\
\hline 32. & Filobasidium stepposum (Golubev \& J.P. Samp.) Xin Zhan Liu, F.Y. Bai, M. Groenew. \& Boekhout & 0.000 & 0.087 \\
\hline 33. & $\begin{array}{l}\text { Genolevuria amylolytica (Á. Fonseca, J. Inácio \& Spenc.-Mart.) Xin Zhan Liu, F.Y. Bai, M. } \\
\text { Groenew. \& Boekhout }\end{array}$ & 0.000 & 0.017 \\
\hline 34. & $\begin{array}{l}\text { Hamamotoa lignophila (I. Dill, C. Ramírez \& A.E. González) Q.M. Wang, F.Y. Bai, M. Groenew. \& } \\
\text { Boekhout }\end{array}$ & 0.000 & 1.040 \\
\hline 35. & Hydnaceae & 0.083 & 0.000 \\
\hline 36. & Hygrophoraceae & 0.083 & 0.017 \\
\hline 37. & Hymenochaetales & 0.124 & 0.000 \\
\hline 38. & Inocybe sp. & 0.000 & 0.884 \\
\hline 39. & $\begin{array}{l}\text { Itersonilia pannonica (Niwata, Tornai-Leh., T. Deák \& Nakase) Xin Zhan Liu, F.Y. Bai, J.Z. } \\
\text { Groenew. \& Boekhout }\end{array}$ & 0.000 & 0.156 \\
\hline 40. & Kockovaella machilophila Cañ.-Gib., M. Takash., Sugita \& Nakase & 0.000 & 0.676 \\
\hline 41. & Kondoa aeria Á. Fonseca, J.P. Samp. \& Fell & 0.000 & 0.017 \\
\hline 42. & Kriegeria eriophori Bres. 1891 & 0.000 & 0.156 \\
\hline 43. & Kurtzmanomyces & 0.000 & 0.035 \\
\hline 44. & Kwoniella pini (Golubev \& I. Pfeiff.) Xin Zhan Liu, F.Y. Bai, M. Groenew. \& Boekhout & 0.000 & 0.139 \\
\hline 45. & Laetiporus sulphureus (Bull.) Murrill & 0.000 & 3.727 \\
\hline 46. & Leucosporidiales & 0.000 & 0.017 \\
\hline 47. & Leucosporidiella creatinivora (Golubev) J.P. Samp. & 0.000 & 0.139 \\
\hline 48. & $\begin{array}{l}\text { Leucosporidium drummii Yurkov, A.M. Schäfer \& Begerow + L. fasciculatum Babeva \& Lisichk. + } \\
\text { Leucosporidium sp. }\end{array}$ & +0.000 & 0.416 \\
\hline 49. & Luellia recondita (H.S. Jacks.) K.H. Larss. \& Hjortstam & 0.000 & 0.121 \\
\hline 50. & Malassezia restricta E. Guého, J. Guillot \& Midgley & 0.371 & 0.000 \\
\hline 51. & Mastigobasidium intermedium Golubev & 0.000 & 0.017 \\
\hline 52. & Microbotryomycetes & 0.000 & 0.485 \\
\hline 53. & $\begin{array}{l}\text { Microsporomyces pini (C.H. Pohl, M.S. Smit \& Albertyn) Q.M. Wang, F.Y. Bai, M. Groenew. \& } \\
\text { Boekhout }\end{array}$ & 0.000 & 0.104 \\
\hline 54. & Microstroma album (Desm.) Sacc. & 0.330 & 0.087 \\
\hline 55. & Mrakia frigida (Fell, Statzell, I.L. Hunter \& Phaff) Y. Yamada \& Komag. & 0.000 & 0.017 \\
\hline 56. & $\begin{array}{l}\text { Mycena cinerella (P. Karst.) P. Karst. + M. galericulata (Scop.) Gray + M. megaspora Kauffman + } \\
\text { M. sanguinolenta (Alb. \& Schwein.) P. Kumm. }\end{array}$ & +6.108 & 0.156 \\
\hline 57. & Oberwinklerozyma yarrowii (Á. Fonseca \& Uden) Q.M. Wang, F.Y. Bai, M. Groenew. \& Boekhout & 0.000 & 0.017 \\
\hline 58. & $\begin{array}{l}\text { Papiliotrema perniciosa (Golubev, Gadanho, J.P. Samp. \& N.W. Golubev) Xin Zhan Liu, F.Y. Bai, } \\
\text { M. Groenew. \& Boekhout }\end{array}$ & 0.000 & 0.121 \\
\hline 59. & Peniophora pini (Schleich. ex DC.) Boidin & 0.000 & 0.017 \\
\hline 60. & Phaeotremella skinneri (Phaff \& Carmo Souza) Yurkov \& Boekhout, & 0.000 & 0.017 \\
\hline 61. & $\begin{array}{l}\text { Rhodotorula glutinis (Fresen.) F.C. Harrison + R. nothofagi C. Ramírez \& A.E. González + } \\
\text { Rhodotorula sp. }\end{array}$ & 0.000 & 0.329 \\
\hline 62. & Russulales & 0.041 & 0.017 \\
\hline 63. & Schizophyllum sp. & 0.000 & 0.017 \\
\hline
\end{tabular}




\begin{tabular}{|c|c|c|c|}
\hline \multirow[t]{2}{*}{ No. } & \multirow[t]{2}{*}{ Taxon } & \multirow{2}{*}{ K1 } & \multirow{2}{*}{ K2 } \\
\hline & & & \\
\hline 64. & $\begin{array}{l}\text { Septobasidium broussonetiae C.X. Lu, L. Guo \& J.G. Wei + S. pallidum Couch ex L.D. Gómez \& } \\
\text { Henk }\end{array}$ & 0.000 & 0.130 \\
\hline 65. & Slooffia tsugae (Phaff \& Carmo Souza) Q.M. Wang, F.Y. Bai, M. Groenew. \& Boekhout & 0.000 & 0.035 \\
\hline 66. & Sporidiobolales & 0.000 & 0.156 \\
\hline 67. & Stereum hirsutum (Willd.) Pers. + S. rugosum Pers. & 0.000 & 0.034 \\
\hline 68. & Tausonia pullulans (Lindner) Xin Zhan Liu, F.Y. Bai, J.Z. Groenew. \& Boekhout & 0.000 & 0.624 \\
\hline 69. & Thelephorales & 0.000 & 0.035 \\
\hline 70. & Tremella globispora D.A. Reid + T. indecorata Sommerf. + Tremella sp. & 0.000 & 0.416 \\
\hline 71. & Tremellales & 0.000 & 0.659 \\
\hline 72. & Tremellomycetes & 0.000 & 1.179 \\
\hline 73. & Trichosporon otae Sugita, Takshima \& Kikuchi & 3.260 & 0.000 \\
\hline 74. & Tulasnella sp. & 0.330 & 0.000 \\
\hline 75. & $\begin{array}{l}\text { Vishniacozyma carnescens (Verona \& Luchetti) Xin Zhan Liu, F.Y. Bai, M. Groenew. \& Boekhout } \\
+ \text { + V. victoriae (M.J. Montes, Belloch, Galiana, M.D. García, C. Andrés, S. Ferrer, Torr.-Rodr. \& J. } \\
\text { Guinea) Xin Zhan Liu, F.Y. Bai, M. Groenew. \& Boekhout }\end{array}$ & 0.083 & 0.208 \\
\hline 76. & Vonarxula javanica (Arx \& Weijman) Q.M. Wang, F.Y. Bai, M. Groenew. \& Boekhout & 0.000 & 0.087 \\
\hline \multirow[t]{2}{*}{77.} & Yunzhangia auriculariae (Nakase) Q.M. Wang, F.Y. Bai, M. Groenew. \& Boekhout & 0.000 & 0.017 \\
\hline & Frequency of Basidiomycota & 11.804 & 21.928 \\
\hline \multicolumn{4}{|c|}{ Zygomycota } \\
\hline 1. & Mortierella hyalina (Harz) W. Gams & 0,247627 & \\
\hline 2. & Umbelopsis isabellina (Oudem.) W. Gams & 0,247627 & \\
\hline \multicolumn{4}{|c|}{ Others } \\
\hline \multicolumn{4}{|c|}{ Plantae } \\
\hline 1. & Anthophyta & 0 & 0,034668 \\
\hline 2. & Chlorophyta & 0,288898 & 1,716069 \\
\hline 3. & Plantae & 0,123813 & 0,225342 \\
\hline \multicolumn{4}{|c|}{ Protista } \\
\hline 1. & Cercozoa sp. & 0,165085 & 0,554689 \\
\hline \multicolumn{4}{|c|}{ Frequency of Oters } \\
\hline 1. & No sequence in the database UNITE & 19,27363 & 12,98319 \\
\hline 2. & Non-cultivable fungi & 12,79406 & 5,806899 \\
\hline 3. & Number of isolates & 100 & 100 \\
\hline 4. & Number of fungi isolates & 80,14858 & 84,48605 \\
\hline
\end{tabular}

